\title{
Immunogenicity assessment of Clostridium perfringens type D epsilon toxin epitope-based chimeric construct in mice and rabbit
}

\author{
Ajay Pratap Singh ${ }^{1}\left[\right.$. Shyama N. Prabhu ${ }^{2}$. Viswas K. Nagaleekar ${ }^{3} \cdot$ Saroj K. Dangi ${ }^{3} \cdot$ Chandan Prakash $^{4}$. \\ Vijendra Pal Singh ${ }^{5}$
}

Received: 16 March 2020 / Accepted: 17 August 2020 / Published online: 26 August 2020

(c) King Abdulaziz City for Science and Technology 2020

\begin{abstract}
Epsilon toxin (Etx) belongs to family of pore-forming toxin and is produced by Clostridium perfringens type D. The Etx toxin is responsible for the pathogenesis of enterotoxaemia in sheep and goats, and occasionally in other livestock animals. The present study aimed to develop a Clostridium perfringens epsilon toxin-based chimeric epitope construct having immunodominant B-cell epitope and universal T-cell epitope and its immunogenicity was evaluated in mice and rabbit. An artificial chimeric epitope construct (CEC) was prepared by joining tandem repeats of a peptide containing amino acids (aa) 134-145 of epsilon toxin B-cell epitope and universal T-cell epitopes. The CEC was expressed in the Escherichia coli following codon optimization for efficient translational efficiency and purified by affinity chromatography. The antigenic reactivity of r-CEC proteins was confirmed by western blot with rabbit anti-r-Etox hyperimmune sera. The immunogenicity of the recombinant single CEC was examined in mice and rabbit by indirect ELISA. It was found that r-CEC yielded high titers of neutralizing antibodies $(\geq 1.035 \mathrm{IU} / \mathrm{ml})$ in immunized mice and rabbit. The potency of chimeric protein immunized serum was observed to be higher than the recommended level $(0.1-0.3 \mathrm{IU} / \mathrm{ml})$ for protection in sheep and goats. This indicated the potential ability of the chimeric protein as a vaccine candidate. This further requires studying the immune response in targeted host species (sheep and goat).
\end{abstract}

Keywords Enterotoxaemia $\cdot$ Clostridium perfrienges $\cdot$ Epsilon toxin $\cdot$ Recombinant $\cdot$ B-cell epitope

Ajay Pratap Singh

drajay_vet@yahoo.co.in

Shyama N. Prabhu

https://www.researchgate.net/profile/Shyama_Prabhu

Viswas K. Nagaleekar

https://scholar.google.co.in/citations?user $=\mathrm{cR}$

28JLYAAAAJ\&hl=en

Saroj K. Dangi

https://www.researchgate.net/scientific-contributions/204499

8288-Saroj-K-Dangi

Chandan Prakash

https://www.researchgate.net/scientific-contributions/205992

1277_C_Prakash

Vijendra Pal Singh

https://www.researchgate.net/scientific-contributions/508540

16-Vijendra-Pal-Singh
1 Department of Veterinary Microbiology, College of Veterinary and Animal Science, COVSc.\&AH, U.P. Pandit Deen Dayal Upadhyaya Pashu Chikitsa Vigyan Vishwavidyalaya Evam Go Anusandhan Sansthan (DUVASU), Mathura, UP 281001, India

2 Department of Veterinary Pathology, COVSc.\&AH, U.P. Pandit Deen Dayal Upadhyaya Pashu Chikitsa Vigyan Vishwavidyalaya Evam Go Anusandhan Sansthan (DUVASU), Mathura, UP 281001, India

3 Division Bacteriology and Mycology, Indian Veterinary Reaserch Institute (IVRI), Izatnagar, Bareilly, Uttar Pradesh 243 122, India

4 Centre for Advance Animal Research and Diagnosis, Indian Veterinary Reaserch Institute (IVRI), Izatnagar, Bareilly, Uttar Pradesh 243 122, India

5 National Institute of High Security Animal Disease (NISHAD), Bhopal, Madhya Pradesh 462021, India 


\section{Introduction}

Sheep and goat farming has an important role in securing livelihood for small farmers, especially in arid and semi-arid region. It helps in providing a regular source of income when agriculture fails; due to climatic or any other reason (Gupta et al. 2011). Enterotoxemia (pulpy kidney disease) due to Clostridium perfringens has been reported to cause a devastating impact on small ruminant farming (Singh and Prasad 2008) and the type D epsilon toxin produced by the $C$. perfringens plays a vital role in pathogenesis of the disease (Souza et al. 2010). Etx is produced as an inactive prototoxin in the gastrointestinal tract of animals and transforms into very potent toxin upon proteolytic cleavage of $13 \mathrm{~N}$-terminal residues and the 29 C-terminal amino acids (Popoff 2011).

Feeding management and herd vaccination are the only ways for disease prevention since treatment is of limited value if any, considering the acute nature of the disease (Veschi et al. 2006; Metre 2010). The acceptance of the conventional vaccines based on inactivated whole-cell bacteroid or heat-inactivated culture supernatants for herd health program has largely been limited because of local inflammatory reactions, nonspecific and uncontrolled immune response and short-term immunity in vaccinated animals (Chandran et al. 2010). The adjuvanted toxoid vaccine preparation needs stringent quality control checks for residual toxicity in various batches of vaccines regularly (Lobato et al. 2010).

Recombinant DNA technology-based new generation vaccines have a certain advantage over conventional vaccines (Alarcon et al. 1999). Production of recombinant epsilon toxin in Escherichia coli is advantageous, because it does not require strict anaerobic conditions and there is direct utilization of insoluble fraction of the recombinant toxin, thus reducing the production cost by avoiding protein purification and concentration processes (Lobato et al. 2010). The main disadvantage of recombinant toxoid vaccine over the conventional vaccines is that the expressed fragment or recombinant toxin still possesses the toxic property and hence require inactivation by formalin treatment. Epsilon toxin (Etx) is known to be one of the most potent biological toxins and has been included in the Centers for Disease Control and Prevention (CDC) category $\mathrm{B}$ biological agent. The potential hazards while handling the toxin during the manufacture of the toxoid vaccine as well as the biosecurity threat emanating from its misuse are grave challenges of concern (Berger et al. 2016). Recent knowledge about the crystal structure of toxin has paved the way for the development of new generation safer vaccines by rational modifications of protein. The resulting modifications will abolish the toxicity; however, the immunological identity of the toxin will be conserved. This, in turn, could eliminate the need for toxoidation and safety concerns (Stiles et al. 2013).

Immunity to a single (conformational) epitope on the toxin is sufficient to protect against purified epsilon toxin and infection with $C$. perfringens type B and D (Stiles et al. 2013). The epsilon toxin epitope recognized by the protective monoclonal antibody has been mapped and found to overlap the putative membrane inserting loop (Percival et al. 1990). Vaccines based on protective and neutralizing epitopes are safer in handling; easy to produce by recombinant technologies and significantly reduce the vaccine-associated adverse reactions (McClane 2010; Cao et al. 2013). Minigene epitope-based vaccines have been used successfully against viral, bacterial, and parasitic pathogens with various degrees of success (Chan et al. 2000; Dong et al. 2002; Zhang et al.2009; Liu et al. 2006; Shao et al. 2011; Kaushik et al. 2013; Bhatia et al. 2014).

In the present study, a chimeric epitope construct (CEC) was designed by fusion of immunodominant $\mathrm{B}$-cell and universal T-cell epitope gene of $C$. perfringens type $\mathrm{D}$ epsilon toxin. After the expression of CEC and purification of the chimeric protein, the humoral immune response of chimeric protein was evaluated in mice and rabbit models. The potential ability of hyperimmunized sera to neutralize epsilon toxin was evaluated by indirect ELISA.

\section{Materials and methods}

\section{Designing of chimeric epitope construct (CEC)}

The B-cell antigenic epitope (SFANTNTNTNSK), which corresponds to amino acids 134-145 of epsilon toxin, was chosen for the preparation of CEC (McClane 2010). In silico analysis of the predicted binding motifs and the antigenic intrinsic properties of the selected epitope were done using peptide prediction programs DNASTAR (USA). The CEC was designed by sequential linking of the tandem repeats containing three copies of an epsilon toxin B-cell epitope and universal T-cell epitope, joined together by immunoglobulin hinge region and separated by a linker sequence. The schematic illustration of CEC encoding a polypeptide of 125 amino acid residues is shown in Fig. 1 . The constructed amino acid sequence was reverse translated into nucleotide sequence followed by codon optimization for the efficient heterologous expression in E. coli (Maloy 1996). Gensmart ${ }^{\mathrm{Tm}}$ codon optimization (Genscript, USA) was used to select high-frequency codon, specific for E. coli (Fig. 2). The CEC was custom synthesized by GenScript (USA) gene synthesis service and cloned in pUC-57-kan vector. The presence of insert sequence in 


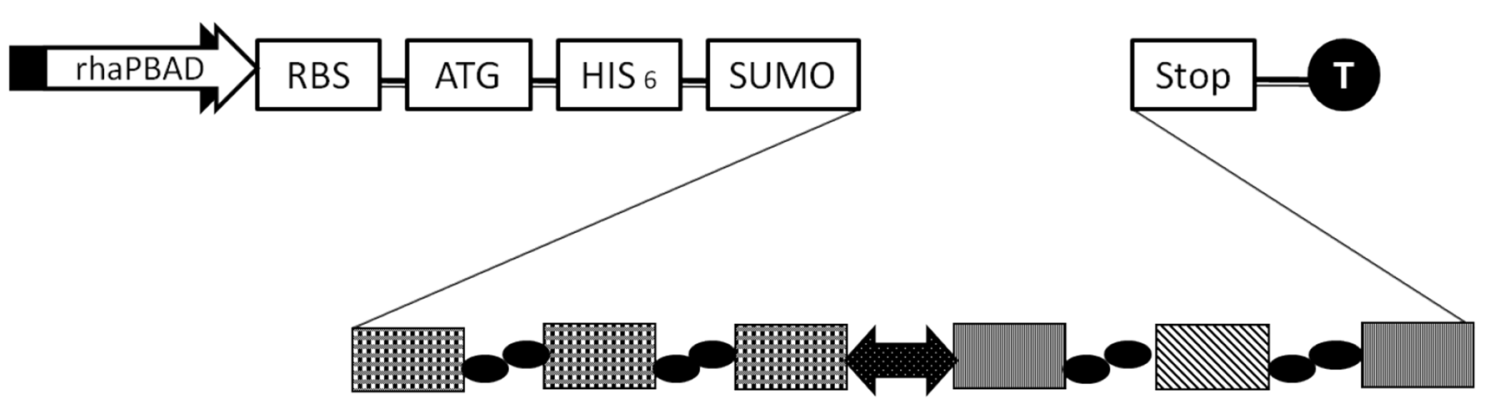

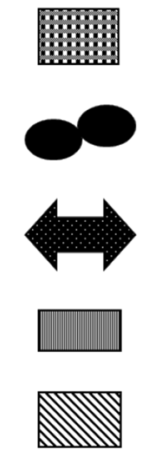

Etx $B$ cell epitope

Linker sequence

IgG heavy chain Hinge region sequence (Homo sapience)

Universal T-cell epitope -1

Universal T-cell epitope 2
SFANTNTNTNSK

GGGGSS

GTCPPCPAP

QYIKANSKFIGITEL

FNNFTVSFWLRVPKVSASHLE
Fig. 1 Design and construction of the chimeric epitope construct (CEC). The CEC was constructed from tandem repeats of three B-cell epitopes and universal T-cell epitopes each, linked by IgG heavy chain hinge region. Glycine and serine linker is used as a spacer between each epitope. CEC was cloned into the pRham-N-His SUMO-Kan vector to express the recombinant protein in E. coli $10 \mathrm{G}$ competent cells
Fig. 2 Reverse translation and codon optimization of a CEC gene in schematic view. GC content of the CEC construct sequence after adaption was evaluated to be $56.34 \%$

$$
\frac{\text { ccatggatgagctttgcgaacaccaacaccaacaccaacagcaaaggcggcggcggcagcagcagcttt }}{\text { S F A N T N T N T N }}
$$

gcgaacaccaacaccaacaccaacagcaaaggcggcggcggcagcagcagctttgcgaacaccaac

A $N$ T N T N T N S S F A T N

accaacaccaacagcaaaggcacctgcccgccgtgcccggcgccgcagtatattaaagcgaacagcaaa

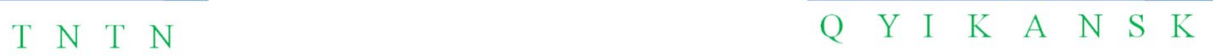

tttattggcattaccgaactggccggcggcggcagcagctttaacaactttaccgtgagcttttggctgcgc

F G I T E L A F N N F T V S F W L R

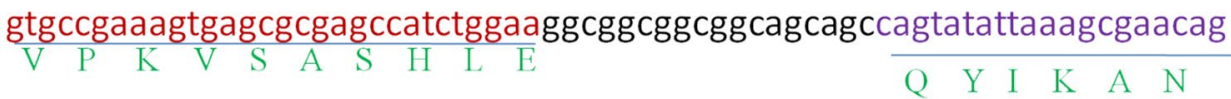

caaatttattggcattaccgaactggccg

S K the vector was confirmed by double-restriction endonuclease digestion of purified plasmid using NcoI and XhoI (Fermentas) and was verified by gene sequencing of the
pUC57 containing synthetic construct using the M13F and M13R primers targeting the flanking site of the multiple cloning sequences. 


\section{Expression of chimeric epitope construct (CEC)}

\section{PCR amplification and Purification of CEC}

The chimeric epitope gene was PCR amplified using the primer pair (pRham-SUMO-syngene-For-5 'CGCGAACAG ATTGGAGGTACGGGCCCCACCCCATGGATG3' and Rev 5 'GTGGCGGCCGCTCTATTATTAA CGAGCATCT AGATGGGC3' targeting the flanking region of the chimeric gene region present in pUC57 vector sequence. The amplification reaction was performed in $25 \mu$ l volume containing $0.2 \mathrm{mM}$ of dNTPs (Fermentas), 25 pmol of each primer (GCC Biotech, India), 1 unit of Pfu polymerase (Fermentas) and $1 \mu \mathrm{l}$ of the recombinant pUC57 plasmid. The PCR program was performed for 30 cycles with denaturation $\left(94^{\circ} \mathrm{C}\right.$ for $30 \mathrm{~s})$, annealing $\left(68^{\circ} \mathrm{C}\right.$ for $\left.45 \mathrm{~s}\right)$ and extension $\left(72{ }^{\circ} \mathrm{C}\right.$ for $3 \mathrm{~min}$ ) in an automated DNA thermal cycler (Eppendorf Mastercycler ${ }^{\circledR}$, USA). The PCR products were analyzed by $1.5 \%$ agarose gel electrophoresis and the gel was eluted using Gel Extraction Kit (Qiagen, USA).

\section{Construction of expression plasmid}

Cloning and transformation were performed by Expresso Rhamnose Cloning and Expression System (Lucigen, USA) as per manufacturer's protocol. Briefly, E. coli $10 \mathrm{G}$ competent cells were thawed on the ice for $10 \mathrm{~min}$ and transferred into a pre-cooled $15 \mathrm{ml}$ centrifuge tube. About $2 \mu \mathrm{l}(200 \mathrm{ng}$ ) of the purified PCR product was added to the $2 \mu \mathrm{l}(25 \mathrm{ng})$ of pRham-N-His SUMO-Kan Vector DNA and mixed gently. The tube containing the mixture of cells and DNA was incubated on ice for $30 \mathrm{~min}$, followed by heat shock at $42^{\circ} \mathrm{C}$ for $45 \mathrm{~s}$. After incubation on ice for $2 \mathrm{~min}, 960 \mu \mathrm{l}$ of the recovery medium was added. The cells were incubated at $37^{\circ} \mathrm{C}$ in a shaking incubator for $2 \mathrm{~h}$ and plated on the LB agar containing Kanamycin (Hi-media) to the final concentration of $30 \mu \mathrm{g} / \mathrm{ml}$ of agar.

\section{Expression and purification of chimeric protein}

The recombinant chimeric protein was affinity-purified in large scale as described elsewhere. The purity of the affinitypurified chimeric protein was analyzed by the SDS-PAGE analysis. The refolding of denatured protein was carried out following the standard protocol (Kashyap and Bhavesh 2013). The concentration of the dialyzed chimera protein was quantified by Bradford assay.

\section{Western blot analysis}

The immunoreactivity of purified protein was confirmed by western blot analysis. The duplicate samples of the fulllength recombinant epsilon toxoid (r-Etox) and chimeric protein (r-CEC) were run on SDS-PAGE. The protein fractions in the SDS-PAGE gel were transferred electrophoretically onto a nitrocellulose membrane (MDI) using semi-dry western blotting apparatus (ATTO, Japan) following standard protocol with minor modifications (Coligan 2002) One half of the membrane was probed by anti-r-Etox hyperimmune sera raised in rabbit, while the other half was probed with anti-r-CEC protein in mouse. The membranes were treated with anti-rabbit and anti-mouse HRPO conjugated antibodies (Santa Cruz Biotechnology), respectively, before developing by the 4-chloro-1-naphthol substrate (Sigma-Aldrich Co.).

\section{Animal vaccination and sample collection}

Six-to-eight-weeks-old female Swiss albino mice, weighing not less than 18-20 g were obtained from Laboratory Animal Resource (LAR) Section, ICAR-Indian Veterinary Research Institute, Izatnagar, Bareilly, Uttar Pradesh, India. The animals were provided laboratory rodent diet and water ad libitum. The experiments were conducted following the ethical guidelines of the Indian Council of agricultural research, India. Ethical approval was obtained by the Institutional Animal Ethics Committee of Indian Veterinary Research Institute, Izatnagar, Bareilly, (vide approval no. F.1-53/2012-13/JD-R). The chimeric protein was diluted in phosphate-buffered saline (PBS) and adjuvanted with aluminum hydroxide gel adjuvant $(0.8 \%$ final volume). To ascertain, dose-dependent immune response, mice were divided into four groups-I, II, III, and IV ( $n=6$ mice per group). Groups II, III, and IV received 25, 50 and $75 \mu \mathrm{g}$ of chimeric protein, respectively, through intramuscular injection of hind-leg quadriceps in two doses at the biweekly interval. The animals of group I (control group) were inoculated with PBS. Mice were bled by retro-orbital venipuncture at the day of immunization for the collection of pre-immune sera and weekly intervals up to nine weeks post-immunization. Pooled serum samples were stored at $-20^{\circ} \mathrm{C}$ for further assays.

\section{Evaluation of immune response by indirect enzyme-linked immunosorbent assay}

The immune response against chimeric protein was determined using indirect ELISA. Briefly, 96-well flat-bottom Immuno plates (Nunc) were coated with $0.1 \mu \mathrm{g} /$ well of purified recombinant epsilon toxoid (r-Etox) in $100 \mu$ coating buffer (0.05 M carbonate-bicarbonate buffer, $\mathrm{pH} 9.6)$ and incubated at $4{ }^{\circ} \mathrm{C}$ overnight. The plates were washed with washing buffer ( $0.05 \%$ Tween 20 in PBS) five times and nonspecific binding sites were blocked with $200 \mu \mathrm{PBS}$ (pH 7.4) containing 5\% skimmed milk at $37{ }^{\circ} \mathrm{C}$ for $1 \mathrm{~h}$. Then after washing, $100 \mu \mathrm{l}$ of 1:100 dilutions of mice sera samples in PBS (pH 7.4) containing 0.05\% Tween 20 and $1 \%$ BSA was 
added, incubated at $37{ }^{\circ} \mathrm{C}$ for $1 \mathrm{~h}$. After that, the washing step was repeated, then $100 \mu \mathrm{l} /$ well of 1:5000 dilution of goat anti-mouse HRPO conjugated IgG (Santa Cruz Biotechnology) was added and incubated at $37^{\circ} \mathrm{C}$ for $1 \mathrm{~h}$. After washing, the bound antibodies were detected after incubation with $100 \mu \mathrm{l}$ of $3 \mathrm{mM}$ orthophenylene di-amine substrate system (Sigma-Aldrich Co.) for $15 \mathrm{~min}$. The color reaction was terminated by adding $100 \mu \mathrm{l} 3 \mathrm{~N} \mathrm{H}_{2} \mathrm{SO}_{4}$ and the absorbance values were obtained using a microplate reader (Biorad, USA) at $492 \mathrm{~nm}$. Serum antibody concentration titers among different groups at different time intervals were compared and analyzed using suitable statistical methods.

\section{Evaluation of epsilon toxin neutralization potential of chimeric protein}

Epsilon toxin neutralization potential of chimeric protein was evaluated by indirect ELISA following the Veterinary Biological Testing Protocol of the United States Department of Agriculture Center (SAM 217.05). Briefly, Healthy New Zealand white rabbits $(n=6)$ were inoculated subcutaneously with $200 \mu \mathrm{g}$ chimeric protein antigen in PBS + aluminum hydroxide gel adjuvant ( $0.8 \%$ final volume) and bled 5ive weeks later. Equal portions of serum, not less than $0.2 \mathrm{ml}$, from each rabbit were pooled and stored at $-70^{\circ} \mathrm{C}$. The serum was assayed for antitoxin antibodies content by indirect ELISA. Recombinant epsilon toxoid $(0.1 \mathrm{~g})$ was coated in all the wells of a 96-well microtiter plate. Clostridia rabbit (multicomponent) antiserum BRP batch 1 by the European Directorate for the Quality of Medicines (EDQM) was used as a reference positive serum while pre-immune rabbit serum served as the negative control. Incremental dilutions of all sera (positive control, negative control, and test serum pool) in skim milk diluents were prepared. These dilutions were used to create a standard response curve against which the test sera were compared. A linear regression analysis was performed using data (antitoxin unit concentration vs. absorbance) from the standard reference sera (1-10 IU $/ \mathrm{ml})$. From the equation, the slope, correlation coefficient, and y-intercept of the resultant dose-response line (i.e., standard curve) were determined. The potency (IU/ml) of the test serum pool was calculated by fitting the average absorbance of the test serum pool to the regression line. The titer prediction equation for each form of absorbance in a particular single serum dilution was as follows:

Titre (IU/ml) of test serum pool

$=($ absorbance of test serum pool $-y$ intercept $) /$ slope

\section{Statistical analysis}

All the data were expressed as mean \pm standard error mean (SEM) for statistical analysis. For determining the significance of the observations, data were statistically analyzed by one-way analysis of variance (one-way ANOVA) followed by Tukey $b$ tests or linear regression analysis using GraphPad Prism 5.0 software (La Jolla, USA).

\section{Results}

\section{Cloning and expression of PCR amplified chimeric epitope construct}

The PCR amplification of the chimeric epitope construct produced an amplicon of $444 \mathrm{bp}$ product that was resolved in an agarose gel and purified by gel extraction kit for ligation (Fig. 3). The concentration of purified amplified product was found to be $96 \mathrm{ng} / \mu$ l. Successful cloning was confirmed by colony PCR of selected clones followed by double digestion of plasmid with $\mathrm{NcoI}$ and $\mathrm{XhoI}$ restriction endonuclease enzymes that released desired insert of 444 bp (Fig. 4). The SDS-PAGE analysis of an uninduced and induced fraction of the culture, confirmed the expression of chimeric protein and after purification, The SDS-PAGE analysis of chimeric protein produced an intense band of protein corresponding to $29 \mathrm{kDa}$ size of pre-stained molecular weight marker (Fig. 5). The chimeric protein concentration was determined as $0.725 \mathrm{mg} / \mathrm{ml}$ by Bradford assay.

\section{Immunological characterization of the chimeric protein}

Immunoreactivity of chimeric protein was established by producing a distinct band of $\sim 29 \mathrm{kDa}$ using anti-r-ETx hyperimmune serum as a probe in western blot analysis (Fig. 6a). For further confirmation, the same western blot was repeated using epsilon toxoid as an antigen and

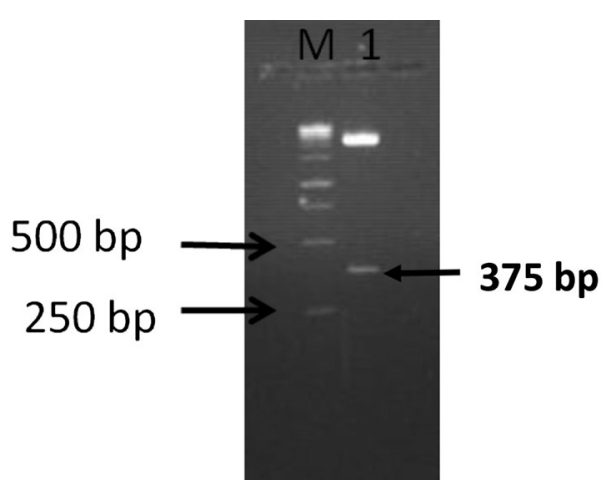

Fig. 3 Digestion products of the recombinant pUC57 vector vector with the restriction enzymes $\mathrm{NcoI}$ and $\mathrm{XhoI}$ in the agarose gel (1\%), Two distinct bands containing the linearized vector pUC57 and the separated fragment with about $375 \mathrm{bp}$ bp size indicating the CEC gene construct (Lane 1), DNA ladder (1 kb DNA ladder) (Lane M) 


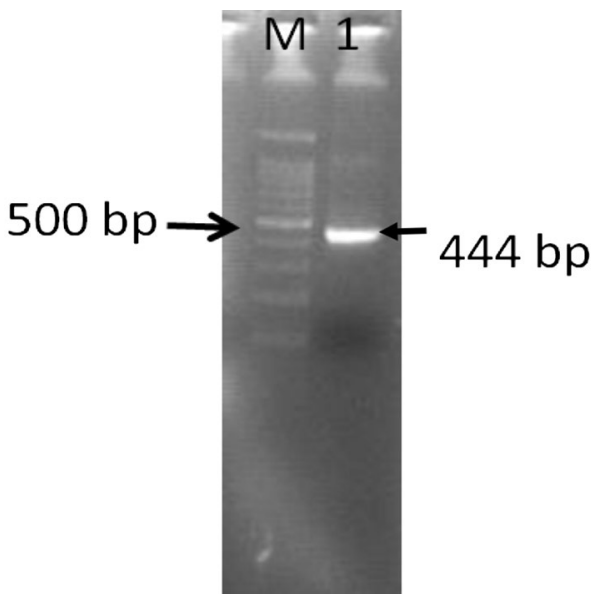

Fig. 4 PCR Amplification of CEC using primer specifically designed for Expresso Rhamnose Cloning and Expression System (Lucigen, USA) using recombinant pUC57 as template in the agarose gel (1.5\%). Lane M: 100 bp DNA ladder marker plus. Lane 1: represents the amplified PCR product of $444 \mathrm{bp}$

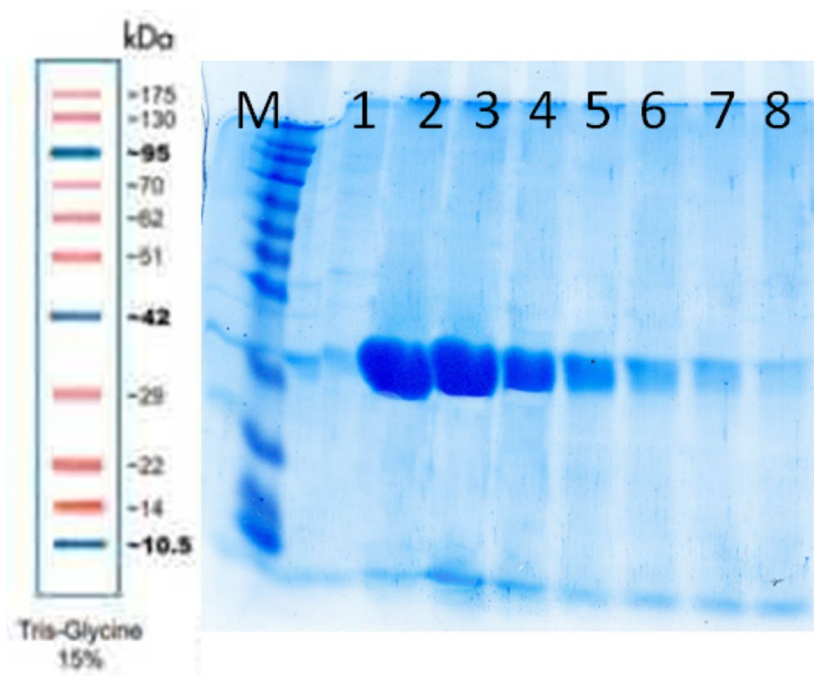

Fig. 5 Coomassie blue-stained SDS-PAGE gel showing expression and purification of r-CEC protein. The total proteins of the E. coli 10G were harvested and r-CEC was affinity purified using Ni-NTA agarose column. The column purified fractions loaded on $12 \%$ (v/v) SDS-PAGE. Lane M: Pre-stained Protein Ladder $(10-170 \mathrm{kDa})$. Lane 1: wash buffer flow-through fraction. Lane 2-8: elution buffer fraction 1-7

hyperimmunized sera against chimeric protein as a probe. The western blot also produced a specific signal at an appropriate size of $\sim 32 \mathrm{kDa}$ (Fig. 6b). This confirms the antigenicity of chimeric protein and its potential ability to induce an immune response in the host.

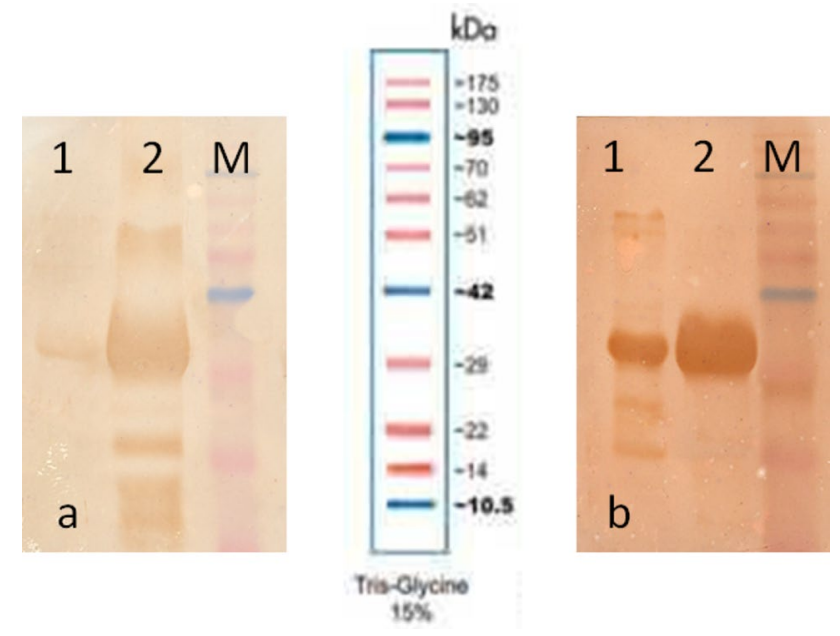

Fig. 6 Western blot analysis of r-CEC and r-Etx. The affinity-purified r-CEC and r-Etx were separated in 12\% SDS-PAGE gel and probed with a rabbit-anti-r-Etx hyperimmune sera $\mathbf{b}$ : mouse-anti-r-CEC antibody. M: Pre-stained protein ladder (10.5-175 kDa). Lane 1: r-CEC protein, Lane 2: r-Etx protein

\section{The immune response against chimeric protein in mice}

For evaluation of immune response, antibody titer against the chimeric protein in mice were measured by optimized indirect ELISA $(0.187 \mu \mathrm{g}$ of $\mathrm{r}$-Etox as coating antigen, 1:3200 primary antibodies, 1:4000 secondary antibodies conjugate dilution). The titer of antigen-specific serum IgG at weekly intervals (Table 1) was expressed as mean OD values \pm standard error. Briefly, in the first week PI, only GII exhibited a significant level of the immune response $(p<0.001)$ compared to the control group. The immune response started to rise from second week onwards in all the immunized groups, but it rose to a significantly higher level $(p<0.001)$ from third week onward that lasted till fifth week PI. After the booster immunization, significant $(p<0.001)$ rise in antibody titer was noticed in all the groups except the control group. In ninth week PI, the serum antibody titer maintained at a significantly higher level $(p<0.001)$ in GIII only. The week-wise mean antibody titer analysis showed higher mean antibody titer in GII post-first and second- week immunization, but in GIII, mean antibody titer remained highest among all the groups post third immunization.

\section{Evaluation of epsilon toxin neutralization potential of chimeric protein}

Epsilon toxin neutralization potential of chimeric protein was indirectly evaluated using internationally recommended indirect ELISA method. The antibody titer of international reference sera and hyperimmune sera against chimeric 
Table 1 Immunogenicity assessment as antibody titre (ELISA OD490) in different vaccinated group

\begin{tabular}{lllllll}
\hline Groups & 1st week & 2nd week & 3rd week & 4th week & 5th week & 9th week \\
\hline Control & $0.320 \pm 0.005^{\mathrm{aA}}$ & $0.315 \pm 0.006^{\mathrm{aA}}$ & $0.320 \pm 0.005^{\mathrm{aA}}$ & $0.333 \pm 0.01^{\mathrm{aA}}$ & $0.324 \pm 0.004^{\mathrm{aA}}$ & $0.343 \pm 0.015^{\mathrm{aA}}$ \\
$25 \mu \mathrm{g}$ & $0.394 \pm 0.005^{\mathrm{cB}}$ & $0.388 \pm 0.006^{\mathrm{cB}}$ & $0.347 \pm 0.005^{\mathrm{bA}}$ & $0.699 \pm 0.01^{\mathrm{cC}}$ & $0.689 \pm 0.013^{\mathrm{cC}}$ & $0.330 \pm 0.007^{\mathrm{aA}}$ \\
$50 \mu \mathrm{g}$ & $0.332 \pm 0.005^{\mathrm{aA}}$ & $0.360 \pm 0.006^{\mathrm{bB}}$ & $0.357 \pm 0.005^{\mathrm{bAB}}$ & $0.720 \pm 0.008^{\mathrm{cD}}$ & $0.743 \pm 0.008^{\mathrm{dD}}$ & $0.433 \pm 0.003^{\mathrm{bC}}$ \\
$75 \mu \mathrm{g}$ & $0.332 \pm 0.004^{\mathrm{aA}}$ & $0.356 \pm 0.006^{\mathrm{bA}}$ & $0.351 \pm 0.007^{\mathrm{bA}}$ & $0.576 \pm 0.009^{\mathrm{bB}}$ & $0.586 \pm 0.005^{\mathrm{bB}}$ & $0.340 \pm 0.005^{\mathrm{aA}}$ \\
\hline
\end{tabular}

Means sharing similar letters (small) in a columns and sharing similar letter (capital) between the rows are statistically non-significant $(p<0.05)$

protein was compared. The neutralizing ability (potency of chimeric protein) was extrapolated by linear regression analysis of indirect ELISA OD value with reference to the international standard serum of known antitoxin neutralizing potential (11 IU). The neutralizing antibody titer of immune sera against chimeric protein was determined to be $1.035 \mathrm{IU} / \mathrm{ml}$.

\section{Discussion}

The most commonly available and extensively used vaccine against $C$. perfringens enterotoxaemia is epsilon toxoidbased vaccines. This requires handling of bacterial culture and production of epsilon toxin followed by adequate chemical inactivation. An alternative approach may be recombinant genetically detoxified epsilon toxin fragment, expressed in E. coli or another easily cultured host, used as a vaccine candidate. It has been reported that a monoclonal antibody against a particular B-cell epitope may provide sufficient protection from enterotoxemia. (Percival et al. 1990; McClane 2010). The location of the epitope, recognized by the protective monoclonal antibody, has been mapped to amino acids 134-145 (peptide sequence SFANTNTNTNSK) and has been found to overlap the putative membrane inserting loop. These antibodies could have utility for the prevention or treatment of disease (McClane 2010). The present study aimed to develop a chimeric B-cell epitope construct (CEC) using the neutralizing epitope (SFANTNTNTNSK) as an alternative to the toxoid-based vaccine. Development of CEC was preferred to epitope peptide vaccine due to drawbacks associated with the peptide vaccine (poor antigenicity, easy proteolysis, and requirement of adjuvant) ( $\mathrm{Li}$ et al. 2014).

The CEC was prepared comprising multiple contiguous tandem repeats of the chosen epitope separated by the linker sequence. The successful construction of fusion proteins relies on the proper choice of a protein linker as the direct fusion of two domains can lead to compromised biological activity by a stearic hindrance from the adjacent repeats (Zhang et al. 2003; Bai et al. 2005). Apart from tandem repeats of the B-cell epitope of epsilon toxin, the universal T-cell epitope was also incorporated in the hypothetical construct because a good immune response against an antigen involves both humoral and cellular immune responses. Immunizations with CEC containing T-cell epitopes may have several advantages compared to full-length proteins (Ishioka et al. 1999). For inducing a strong humoral immune response, protein antigens require activation of antigen-specific T-helper cell via peptide: MHC complex which in turn deliver activating signals to the B cell (Janeway et al. 2001).

For ensuring high translational efficiency, the chimeric epitope construct was codon optimized and expressed in $E$. coli following standard protocol. The customized $376 \mathrm{bp}$ CEC cloned in pUC57 vector and expressed in SUMO vector. The chimeric protein was purified with Ni-NTA affinity chromatography and confirmed with the presence of a specific protein band of $\sim 29 \mathrm{kDa}$. The calculated protein size should correspond to $\sim 15 \mathrm{kD}$ but the increase in molecular mass is due to additional $\mathrm{N}$-terminal 6-His and Sumo tag sequence added in the expression vector. This chimeric protein showed well-defined immunoreactivity with hyperimmune sera raised against r-Etx in rabbit in western blot analysis. It indicates the potential applicability of this chimeric protein as a vaccine candidate. The humoral immune response against epsilon toxin plays an important role in protective immunity against enterotoxaemia (Sojka et al. 1989). For further confirmation of immunogenicity, the humoral immune response against the chimeric protein in swiss albino mice up to 9 weeks PI was measured by indirect ELISA. Mice injected with as little as $25 \mu \mathrm{g}$ of chimera protein showed a significant seroconversion. There were no significant differences in the antibody titers between the groups injected with $25 \mu \mathrm{g}, 50 \mu \mathrm{g}$ and $75 \mu \mathrm{g}$ of chimeric protein up to 5 weeks PI. However, at 9-week PI, only $50 \mu \mathrm{g}$ group (GIII) showed a significant increase in antibody titer. Initially, immune response (antibody titer) enhanced with an increasing dose of antigen up to $50 \mu \mathrm{g}$ but after that, increased antigenic dose did not show any effect on seroconversion. The threshold dose of the chimeric protein antigen was determined to be $50 \mu \mathrm{g}$ that is sufficient to induce a sustained immune response in mice.

The potency of conventional epsilon toxoid-based vaccine is measured by antitoxin antibodies against epsilon toxin in mouse neutralization test (MNT). Severe distress and suffering experienced by the mice and the enormous number of

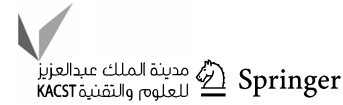


animals used emphasize the need to replace the MNT with in vitro methods like indirect, competitive ELISAs, and cell culture tests (Wood 1991; Uzal et al. 1997, 1998). An indirect ELISA (I-ELISA) has been developed for the estimation of antibodies against epsilon toxin and titers are reported as international units per milliliter (IU/ml). This is considered an alternative of MNT and gives an indication of the potential application of antigen as a vaccine candidate (Smith and Sherman 1994). The same indirect ELISA protocol was used for determining epsilon toxin neutralization potential of antiserum against this chimeric protein.

In the present study, antibody titer against the chimera protein was observed to be $1.035 \mathrm{IU} / \mathrm{ml}, 35$ days PI. Previous studies have shown that the anti-epsilon toxin antibody titer between 0.10 and $0.30 \mathrm{IU} / \mathrm{ml}$ in sheep and $0.25 \mathrm{IU} / \mathrm{ml}$ in goat is considered protective against enterotoxaemia in small ruminant (Bullen and Batty 1957; Uzal et al. 1998). In our study, the antibody titer against the chimeric protein has been found much higher to threshold protective antibody titer, indicated the potential application of this chimeric protein as a vaccine candidate. This further warrants studying immune response and challenging studies in targeted host species.

\section{Conclusion}

The chimeric B-cell epitope construct could produce significant antibody titer in mice. The high antibody titer indicates the potential ability of a chimeric protein to protect the targeted species sheep and goat from enterotoxemia. This further requires studying the immune response in targeted species using chimeric protein as a vaccine candidate. It does not have any residual epsilon toxicity, which makes it safe to be used in sheep and goat.

Acknowledgements The authors are thankful to the Indian Council of Agricultural Research and Director, Indian Veterinary Research Institute, Izatnagar, Bareilly, for providing the infrastructural facility to conduct this study.

Author contributions APS, VKN, and VPS contributed to the study conception. APS and SKD designed and conducted the experiments. Data analysis was performed by APS and SNP. Original Draft was written by APS and edited by CP. All authors read and approved the final manuscript.

Funding There are no financial conflicts of interest to disclose.

\section{Compliance with ethical standards}

Conflict of interest The authors declare that they have no conflict of interest in the publication.

Statement of ethics The present study was conducted following the ethical guidelines of the Indian Council of agricultural research, India.
Ethical approval was obtained by the Institutional Animal Ethics Committee of Indian Veterinary Resaerch Institute, Izatnagar, Bareilly, (vide approval no. F.1-53/2012-13/JD-R).

\section{References}

Alarcon JB, Waine GW, McManus DP (1999) DNA vaccines: technology and application as anti-parasite and anti-microbial agents. Advances in parasitology. Academic Press, Cambridge, pp 343-410

Bai Y, Ann DK, Shen WC (2005) Recombinant granulocyte colonystimulating factor-transferrin fusion protein as an oral myelopoietic agent. Proc Natl Acad Sci 102(20):7292-7296. https://doi. org/10.1073/pnas.0500062102

Berger T, Eisenkraft A, Bar-Haim E, Kassirer M, Aran AA, Fogel I (2016) Toxins as biological weapons for terror-characteristics, challenges and medical countermeasures: a mini-review. Disaster Mil Med 2(1):7. https://doi.org/10.1186/s40696-016-0017-4

Bhatia B, Solanki AK, Kaushik H, Dixit A, Garg LC (2014) B-cell epitope of beta toxin of Clostridium perfringens genetically conjugated to a carrier protein: expression, purification and characterization of the chimeric protein. Protein Exp Purif 102:38-44. https://doi.org/10.1016/j.pep.2014.06.014

Bullen JJ, Batty II (1957) Enterotoxaemia of sheep. Vet Rec 69:1268-1276

Cao Y, Lu Z, Li Y, Sun P, Li D, Li P, Bai X, Fu Y, Bao H, Zhou C, Xie B (2013) Poly (I: C) combined with multi-epitope protein vaccine completely protects against virulent foot-and-mouth disease virus challenge in pigs. Antivir Res 97(2):145-153. https://doi. org/10.1016/j.antiviral.2012.11.009

Chandran D, Naidu SS, Sugumar P, Rani GS, Vijayan SP, Mathur D, Garg LC, Srinivasan VA (2010) Development of a recombinant epsilon toxoid vaccine against enterotoxemia and its use as a combination vaccine with live attenuated sheep pox virus against enterotoxemia and sheep pox. Clin Vaccine Immunol 17(6):10131016. https://doi.org/10.1128/CVI.00013-10

Chan EW, Wong HT, Cheng SC, Yan WY, Zheng ZX, Sheng ZT, Zhu LQ, Xie Y (2000) An immunoglobulin G based chimeric protein induced foot-and-mouth disease specific immune response in swine. Vaccine 19(4-5):538-546. https://doi.org/10.1016/S0264 $-410 \mathrm{X}(00) 00186-9$

Coligan JE (2002) Current protocols in protein science. Wiley, New York

Dong XN, Wei K, Liu ZQ, Chen YH (2002) Candidate peptide vaccine induced protection against classical swine fever virus. Vaccine 21(3-4):167-173. https://doi.org/10.1016/S0264-410X(02)00466 $-8$

Gupta DC, Suresh A, Sethi D (2011) Economics of sheep and goat rearing in semi-arid region of Rajasthan. Indian J Small Rumin 17(2):215-221

Ishioka GY, Fikes J, Hermanson G, Livingston B, Crimi C, Qin M, del Guercio MF, Oseroff C, Dahlberg C, Alexander J, Chesnut RW (1999) Utilization of MHC class I transgenic mice for development of minigene DNA vaccines encoding multiple HLArestricted CTL epitopes. J Immunol 162(7):3915-3925

Janeway CA, Capra JD, Travers P, Walport M (2001) Immunobiology: the immune system in health and disease, 5th edn. Churchill Livingstone, New York

Kashyap M, Bhavesh NS (2013) Structural characterization of the RNA binding domain of human stem loop binding protein. J Proteins Proteom 4(2): 109-114

Kaushik H, Deshmukh S, Mathur DD, Tiwari A, Garg LC (2013) Recombinant expression of in silico identified B-cell epitope of 
epsilon toxin of Clostridium perfringens in translational fusion with a carrier protein. Bioinformation 9(12):617. https://doi. org/10.6026/97320630009617

Liu S, Tu C, Wang C, Yu X, Wu J, Guo S, Shao M, Gong Q, Zhu Q, Kong X (2006) The protective immune response induced by B cell epitope of classical swine fever virus glycoprotein E2. J Virol Methods 134(1-2):125-129. https://doi.org/10.1016/j.jviro met.2005.12.008

Li W, Joshi MD, Singhania S, Ramsey KH, Murthy AK (2014) Peptide vaccine: progress and challenges. Vaccines 2(3):515-536

Lobato FC, Lima CG, Assis RA, Pires PS, Silva RO, Salvarani FM, Carmo AO, Contigli C, Kalapothakis E (2010) Potency against enterotoxemia of a recombinant Clostridium perfringens type D epsilon toxoid in ruminants. Vaccine 28(38):6125-6127. https:// doi.org/10.1016/j.vaccine.2010.07.046

Maloy SR, Stewart VJ, Taylor RK, Miller SI (1996) Genetic analysis of pathogenic bacteria. Trends Microbiol 4(12):504

McClane BA (2010) Clostridium perfringens type C isolates rapidly upregulate their toxin production upon contact with host cells: new insights into virulence? Virulence 1(2):97-100. https://doi. org/10.4161/viru.1.2.10679

Metre DV (2010) Enterotoxemia (overeating disease) of sheep and goats. Colorado State University, Colorado

Percival DA, Shuttleworth AD, Williamson ED, Kelly DC (1990) Anti-idiotypic antibody-induced protection against Clostridium perfringens type D. Infect Immun 58(8):2487-2492

Popoff MR (2011) Multifaceted interactions of bacterial toxins with the gastrointestinal mucosa. Future Microbiol 6(7):763-797. https:// doi.org/10.2217/fmb.11.58

Shao JJ, Wong CK, Lin T, Lee SK, Cong GZ, Sin FW, Du JZ, Gao SD, Liu XT, Cai XP, Xie Y (2011) Promising multiple-epitope recombinant vaccine against foot-and-mouth disease virus type O in swine. Clin Vaccine Immunol 18(1):143-149. https://doi. org/10.1128/CVI.00236-10

Singh B, Prasad S (2008) Modeling of economic losses due to some important diseases in goats in India. Agric Econ Res Rev 21(2):297-302. https://doi.org/10.22004/ag.econ.47686

Smith MC, Sherman DM (1994) Goat medicine. Lea and Febiger, Philadelphia
Sojka MG, White VJ, Thorns CJ, Roeder PL (1989) The detection of Clostridium perfringens epsilon antitoxin in rabbit serum by monoclonal antibody based competition ELISA. J Biol Stand 17(2):117-124. https://doi.org/10.1016/0092-1157(89)90002-4

Souza AM, Reis JK, Assis RA, Horta CC, Siqueira FF, Facchin S, Alvarenga ER, Castro CS, Salvarani FM, Silva RO, Pires PS (2010) Molecular cloning and expression of epsilon toxin from Clostridium perfringens type D and tests of animal immunization. Genet Mol Res 9(1):266-276. https://doi.org/10.4238/vol9-1gmr7 11

Stiles BG, Barth G, Barth H, Popoff MR (2013) Clostridium perfringens epsilon toxin: a malevolent molecule for animals and man? Toxins 5(11):2138-2160. https://doi.org/10.3390/toxins5112138

Uzal FA, Nielsen K, Kelly WR (1997) Detection of Clostridium perfringens type $\mathrm{D}$ epsilon antitoxin in serum of goats by competitive and indirect ELISA. Vet Microbiol 57(2-3):223-231. https://doi. org/10.1016/S0378-1135(97)00122-3

Uzal FA, Bodero DA, Kelly WR, Nielsen K (1998) Variability of serum antibody responses of goat kids to a commercial Clostridium perfringens epsilon toxoid vaccine. Vet Rec 143(17):472-474. https ://doi.org/10.1136/vr.143.17.472

Veschi JL, Dutra IS, Miyakawa ME, Perri SH, Uzal FA (2006) Immunoprophylactic strategies against enterotoxemia caused by Clostridium perfringens type D in goats. Pesqui Vet Bras 26(1):51-54. https://doi.org/10.1590/S0100-736X2006000100011

Wood KR (1991) An alternative to the toxin neutralization assay in mice for the potency testing of the Clostridium tetani, Clostridium septicum, Clostridium novyi type B and Clostridium perfringens type $\mathrm{D}$ epsilon components of multivalent sheep vaccines. Biologicals 19(4):281-286. https://doi.org/10.1016/S1045 -1056(05)80016-8

Zhang HY, Sun SH, Guo YJ, Zhou FJ, Chen ZH, Lin Y, Shi K (2003) Immune response in mice inoculated with plasmid DNAs containing multiple-epitopes of foot-and-mouth disease virus. Vaccine 21(32):4704-4707. https://doi.org/10.1016/S0264 $-410 X(03) 00519-X$

Zhang J, Yun J, Shang Z, Zhang X, Pan B (2009) Design and optimization of a linker for fusion protein construction. Prog Nat Sci 19(10):1197-1200. https://doi.org/10.1016/j.pnsc.2008.12.007 